Plant Tissue Cult. \& Biotech. 22(1): 73-81, 2012 (June)

$\overline{\mathrm{PTC} \& \mathrm{~B}}$

\title{
Molecular Characterization of Mungbean Yellow Mosaic Disease and Coat Protein Gene in Mungbean Varieties of Bangladesh
}

\author{
Mohammad Nurul Islam*, Sonia Khan Sony and \\ Rita Sarah Borna
}

Plant Breeding and Biotechnology Laboratory, Department of Botany, University of Dhaka, Dhaka-1000, Bangladesh

Key words: MYMV, Coat protein, PCR, Begomovirus, RCA

\begin{abstract}
Mungben yellow mosaic virus (MYMV), a member of the genus begomovirus causing major yield loss of mungbean. Development of MYMV tolerant/resistant varieties using an antiviral strategy may be one of the potential options to overcome MYMV diseases. In the present investigation, molecular identification of yellow mosaic disease and characterization of (MYMV) coat protein (CP) gene was attempted. Yellow mosaic symptomatic samples were identified through PCR using conserved region primers designed after alignment of the available $\mathrm{CP}$ sequences in NCBI data base. Sequence analysis of the PCR amplified samples showed $97 \%$ sequence similarities with the coat protein gene of Mungbean Yellow Mosaic India Virus (MYMIV) Bangladesh strain and was designated as MYMIV-BD. This appears to be the first report of the molecular identification of MYMV in Bangladesh.
\end{abstract}

\section{Introduction}

Mungbean (Vigna radiata (L.) Wilczek) is one of the most important pulse crops growing in Bangladesh. It is an Asiatic species of the pan-tropical genus Vigna belongs to the family Leguminosae and sub family Papilionaceae. Mungbean is cultivated in different regions of Bangladesh. Although large amounts of mungbean is extensively cultivated in Bangladesh but its production has not yet been increased substantially. The main reason for low yield is the susceptibility to various viral diseases of which yellow mosaic disease caused by mungbean yellow mosaic virus (MYMV) is the most damaging one (Nariani 1960). MYMV, a member of the family Geminiviridae, popularly known as geminivirus.

*Author for correspondence. <mnurul@du.ac.bd>. 
Geminiviruses are plant viruses characterized by twin icosahedral particles (Thomas et al. 1986). It possesses monopartite or bipartite circular, singlestranded DNA genomes (Ahmed et al. 1991, Navot et al. 1991). Bipartite begomoviruses contains ss-DNA genomes of approximately $2.7 \mathrm{~kb}$. The majority of the begomoviruses are bipartite and the genomic components are referred to DNA-A and DNA-B (Stanley 1983). Geminiviruses have a wide range of host and is transmitted by whitefly (Bemisia tabaci Genn.) but not by mechanical inoculation or by seed sap and soil (Nene 1972, Nariani 1960). In mungbean first symptom of the disease appears on the young leaves in the form of mild scattered yellow specks or spots. The diseased plants usually mature late and bear a few flowers and pods.

The vast majority of plant viruses are non-enveloped. Therefore, the coat protein $(\mathrm{CP})$ contacts the cell and delivers the viral genome into plants. At the end of the infection process, $\mathrm{CP}$ will exit from the infected plant with the genome. Increasingly, it is realized that $\mathrm{CP}$ also plays role as a co-coordinator of the viral infection process, from actively participating in the replication complex to suppress the innate immune response of the plant host (Asurmendi et al. 2004, Qu et al. 2003, Reichert et al. 2007). Studies on CP of plant viruses have been at the vanguard of discoveries in a number of applied areas, including $\mathrm{CP}$ mediated plant resistance (Prins et al. 2009). The use of viral CP as a transgene for producing virus resistant plants is one of the most spectacular successesful achievements in plant biotechnology. First reported resistance was observed against TMV in transgenic tobacco expressing the TMV CP gene (Powell-Abel et al. 1986). Transgenic plants expressing CP showed high resistance to challenge by virions, but not to inoculation with RNA or partially stripped virions (Register and Beachy 1988).

Till now there is no report of using an antiviral strategy to control yellow mosaic disease of mungbean in Bangladesh. In such a context identification of yellow mosaic disease following isolation and characterization of coat protein (CP) gene of mungbean yellow mosaic virus infecting Vigna radiata (L.) Wilczek in Bangladesh was done and reported in this paper.

\section{Materials and Methods}

Mungbean leaves infected with severe yellow mosaic symptoms were collected from different regions of Bangladesh, namely Sher-e-Bangla Agricultural University (SAU) campus, Dhaka and BARI, Gazipur.

A set of PCR primer was designed to identify MYMV infection and to amplify its coat protein gene. To design primers, MYMV coat protein gene sequences were downloaded from NCBI nucleotide data base (Morinaga et al. 
1993). All the downloaded sequences were aligned through BioEdit (Version 7.0) sequence alignment software. After aligning the sequences two regions with maximum sequence homology were selected to design forward (MYMVcpFwd: $5^{\prime}$ ACA CGA GCT CCT CTA CCC CGA TAT CGA ATG 3) and reverse (MYMVcpRev: 5'ACA CGG ATC CGT TGC ATA CAC AGG ATT TG 3) primers.

DNA was isolated from virus infected leaves following modified CTAB method of Islam et al. (2011). For the identification of MYMV infection in the collected samples, isolated DNA samples were subjected to PCR using CP specific primers following an initial denaturation at $95^{\circ} \mathrm{C}$ for 5 min and 30 cycles of denaturation at $94^{\circ} \mathrm{C}$ for $1 \mathrm{~min}$ annealing at $58^{\circ} \mathrm{C}$ for $1 \mathrm{~min}$ and extension at $72^{\circ} \mathrm{C}$ for $30 \mathrm{sec}$ and reaction was completed with final extension at $72^{\circ} \mathrm{C}$ for $5 \mathrm{~min}$. An aliquot from the mix was resolved on $0.8 \%$ agarose gel to check the amplification.

The PCR amplified DNA samples were gel purified and used for automated sequencing. The sequences obtained through automated sequencing were analysed through NCBI BLAST programme to find possible match with other geminivirus coat protein gene reported world-wide in order to confirm that it was from MYMV coat protein gene and to construct a phylogenetic tree.

\section{Results and Discussion}

Yellow mosaic diseased plants were identified to have leaves with yellow mosaic symptom, stunted growth, fewer flowers and smaller pods. In severe infections it was found that the entire leaf may become chlorotic. Other plant parts also become completely yellow (Fig. 1a, b).

Leaves of yellow mosaic virus infected mungbean were tesed for mungbean yellow mosaic virus (MYMV). To confirm the presence of MYMV in the infected plants, total genomic DNA was isolated from the both infected as well as non infected leaf samples. Isolated DNA samples were subjected to PCR using MYMV coat protein (CP) specific primers (MYMV cpFwd and MYMV cpRev) which were designed during this study. The result of PCR analysis was expected to amplify a $\sim 750 \mathrm{bp}$ fragment of the $\mathrm{CP}$ gene. In this study amplification of a bright $\sim 750$ bp band was observed in collected samples (Fig. 1c). Similarly, tomato leaf curl virus (ToLCV) infection was detected in tomato plants at molecular level using ToLCV specific primers (Pandey et al. 2010). One PCR amplified sample from each location was gel purified and used for automated sequencing. The sequences obtained were designated as isolate A (sample from SAU campus, Dhaka) and isolate B (Sample from Gazipur). 

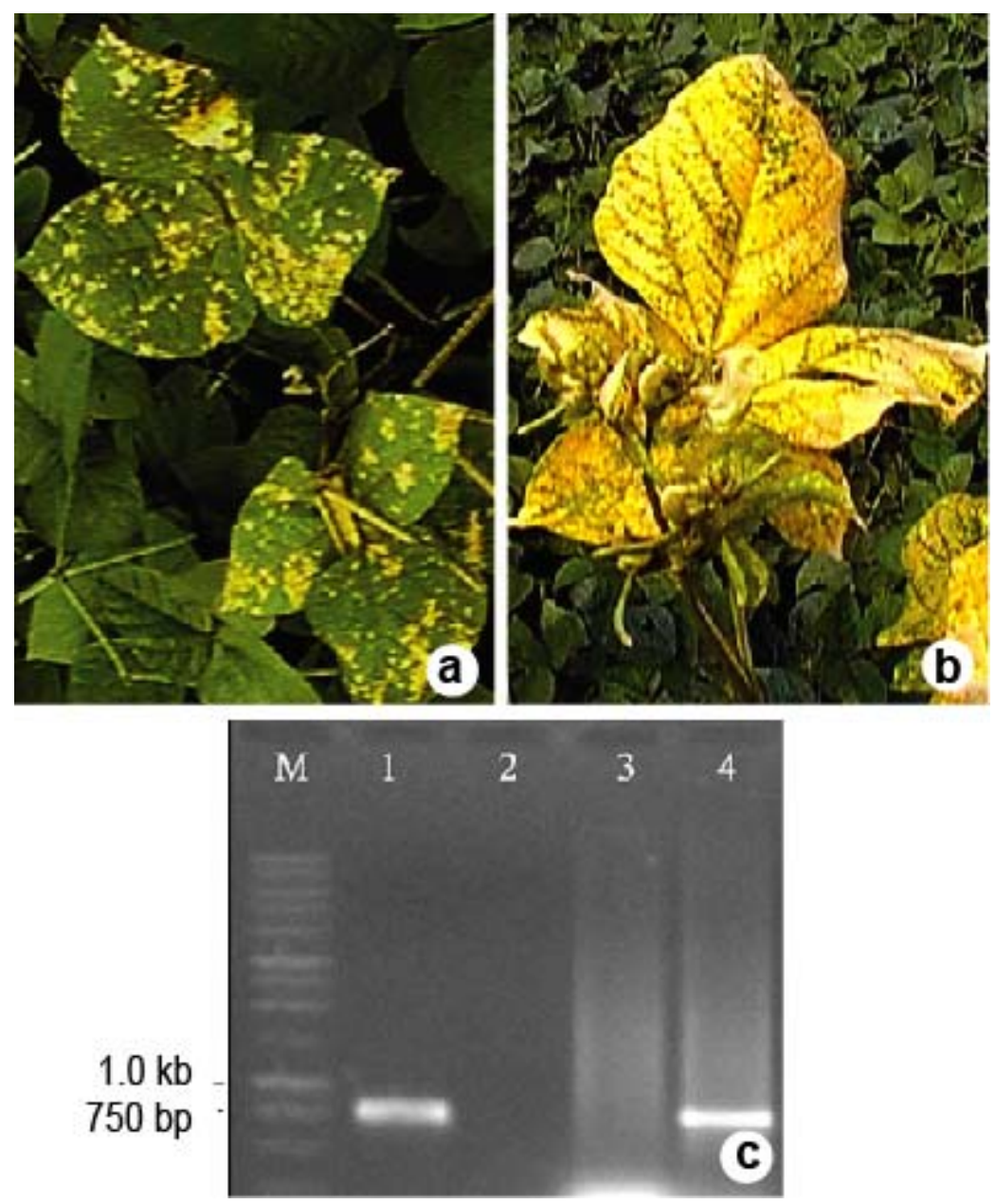

Fig. 1. MYMV infected leaf samples. (a) Early stage of infected leaf, (b) late stage of infection showing severe symptoms of chlorotic lesions and (c) PCR amplification of $750 \mathrm{bp}$ CP gene fragments: Lane 1 and 2 (infected and non-infected samples from SAU campus); Lane 3 and 4 (non-infected and infected samples from Gazipur).

Partial sequences of the two isolates A and B obtained through automated sequencing were analyzed using database searches with other geminivirus sequences. The database searches were carried out by NCBI-BLAST program (http://blast.ncbi.nlm.nih.gov). BLAST searches result showed that the nucleotide sequences of the two isolates (A and B) have sequence similarities and identities with coat protein gene of the different strains of MYMV. But both of them have highest sequence similarity and identity with MYMIV-BD strain (AF314145.1). A 90 per cent nucleotide sequence similarity has been suggested as a guideline for predicting the identity of a distinct begomoviral species ( $<90$ per cent) or a viral strain (> 90 per cent) (Rybicki 1998). From the BLAST analysis it was revealed 
that this two isolates have been shown more than $90 \%$ sequence identity with coat protein gene of others Geminiviruses (Table 1). The sequence of the $\mathrm{CP}$ new isolate was aligned with its sequences of ten MYMIV strains before the phylogenetic analysis using BioEdit software to see the homology or similarity pattern. It was seen that the new CP isolate has above $90 \%$ sequence similarity with others (Fig. 2).

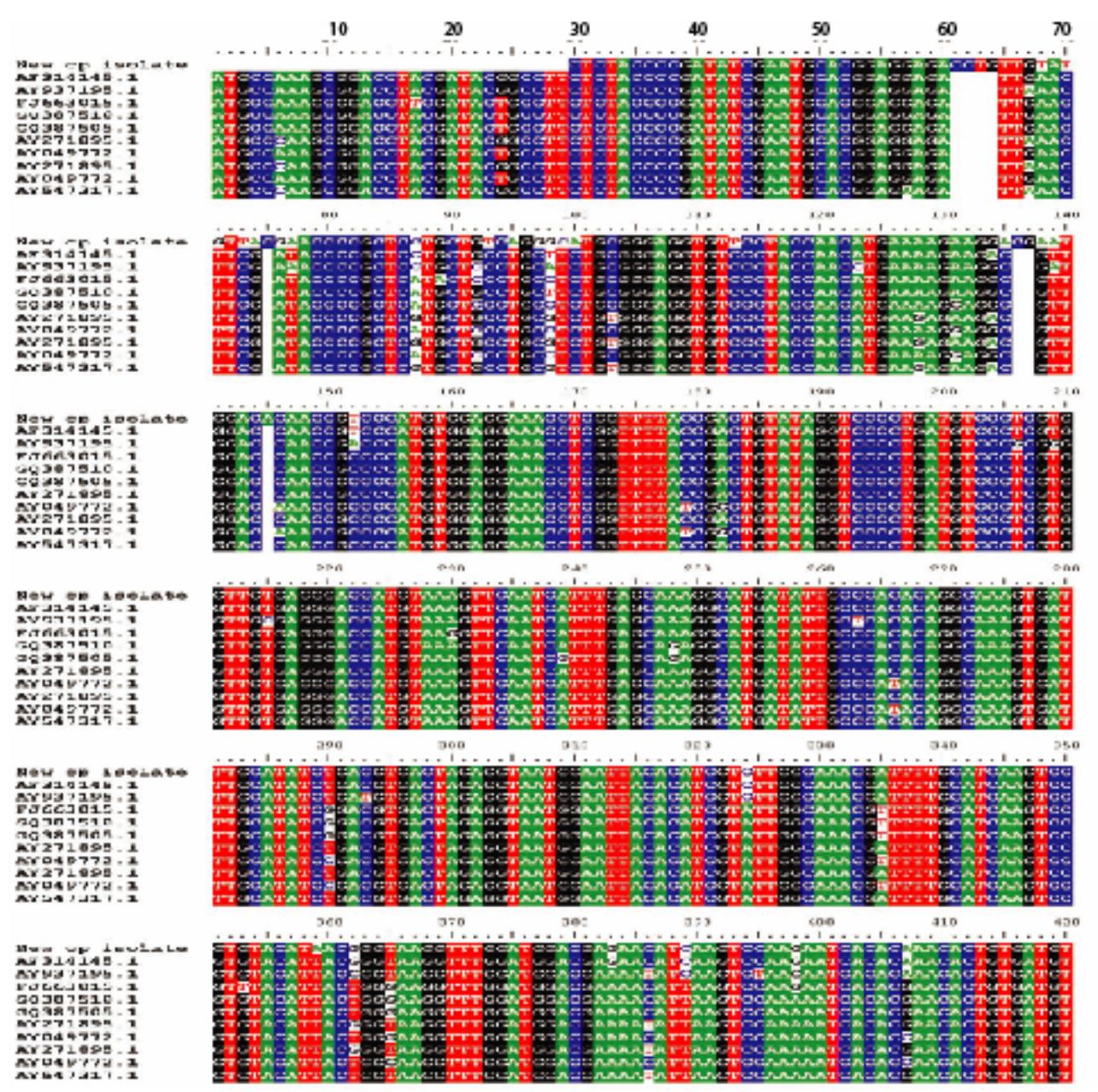

Fig. 2. Multiple sequence alignment of CP gene of new MYMV isolates with selected geminiviruses $\mathrm{CP}$ sequences. The sequence data with less similarities have not been shown.

The phylogenetic relationship of the new $\mathrm{CP}$ isolate with other geminiviruses was judged through BLAST search in NCBI database (Fig. 3). The phylogenetic tree analysis revealed that MYMV CP isolate showed close relationship with MYMIV-BD segment DNA A (AF314145.1) and also has divergent relationship with other geminiviruses $\mathrm{CP}$ gene. 
Table 1. Per cent identities (nucleotide) of new MYMV CP gene isolates A and B with CP gene of ten selected geminiviruses reported world-wide.

\begin{tabular}{|c|c|c|c|c|c|c|}
\hline Accession & Description & $\begin{array}{l}\text { Max. } \\
\text { score }\end{array}$ & $\begin{array}{l}\text { Total } \\
\text { score }\end{array}$ & $\begin{array}{l}\text { Query } \\
\text { coverage } \\
(\%)\end{array}$ & $\begin{array}{c}\mathrm{E} \\
\text { value }\end{array}$ & $\begin{array}{l}\text { Max. } \\
\text { identity } \\
\quad(\%)\end{array}$ \\
\hline AF314145.1 & $\begin{array}{l}\text { Mungbean Yellow Mosaic India } \\
\text { Virus - [Bangladesh] DNA-A, } \\
\text { complete sequence }\end{array}$ & 1112 & 1112 & 90 & 0.0 & 97 \\
\hline AY049772.1 & $\begin{array}{l}\text { Mungbean Yellow Mosaic India } \\
\text { Virus-[Soybean] segment DNA A, } \\
\text { complete sequence }\end{array}$ & 1002 & 1002 & 90 & 0.0 & 94 \\
\hline JN368438.1 & $\begin{array}{l}\text { Mungbean Yellow Mosaic India } \\
\text { Virus Indonesia isolate Brebes } 3 \\
\text { segment DNA-A, complete sequence }\end{array}$ & 1062 & 1062 & 90 & 0.0 & 96 \\
\hline GQ387510.1 & $\begin{array}{l}\text { Mungbean Yellow Mosaic India } \\
\text { Virus isolate MYMIV-Ub05 coat } \\
\text { protein (AV1) gene, complete cds }\end{array}$ & 1038 & 1038 & 90 & 0.0 & 95 \\
\hline GU591171.1 & $\begin{array}{l}\text { Mungbean Yellow Mosaic India } \\
\text { Virus isolate MYMIV-CPKn coat } \\
\text { protein (AV1) gene, complete cds }\end{array}$ & 1027 & 1027 & 90 & 0.0 & 90 \\
\hline GQ387504.1 & $\begin{array}{l}\text { Mungbean Yellow Mosaic India } \\
\text { Virus isolate MYMIV-Mb04 coat } \\
\text { protein (AV1) gene, complete cds }\end{array}$ & 1027 & 1027 & 86 & 0.0 & 96 \\
\hline AY271893.1 & $\begin{array}{l}\text { Mungbean Yellow Mosaic India } \\
\text { Virus - [Akola] segment DNA-A, } \\
\text { complete genome }\end{array}$ & 989 & 989 & 86 & 0.0 & 95 \\
\hline GU591171.1 & $\begin{array}{l}\text { Mungbean Yellow Mosaic India } \\
\text { Virus isolate MYMIV-CPKn coat } \\
\text { protein (AV1) gene, complete cds }\end{array}$ & 1027 & 1027 & 90 & 0.0 & 95 \\
\hline AY547317.1 & $\begin{array}{l}\text { Mungbean Yellow Mosaic India } \\
\text { Virus - [India:Varanasi: } \\
\text { Dolichos:2005] segment DNA-A, } \\
\text { complete sequence }\end{array}$ & 1040 & 1040 & 90 & 0.0 & 95 \\
\hline Y937195.1 & $\begin{array}{l}\text { Mungbean Yellow Mosaic India } \\
\text { Virus clone MBK-A25 segment DNA } \\
\text { A, complete sequence }\end{array}$ & 1062 & 1062 & 90 & 0.0 & 96 \\
\hline AY271895.1 & $\begin{array}{l}\text { Mungbean Yellow Mosaic India } \\
\text { Virus - [Nepal] segment DNA-A, } \\
\text { complete genome }\end{array}$ & 1035 & 1035 & 90 & 0.0 & 95 \\
\hline
\end{tabular}




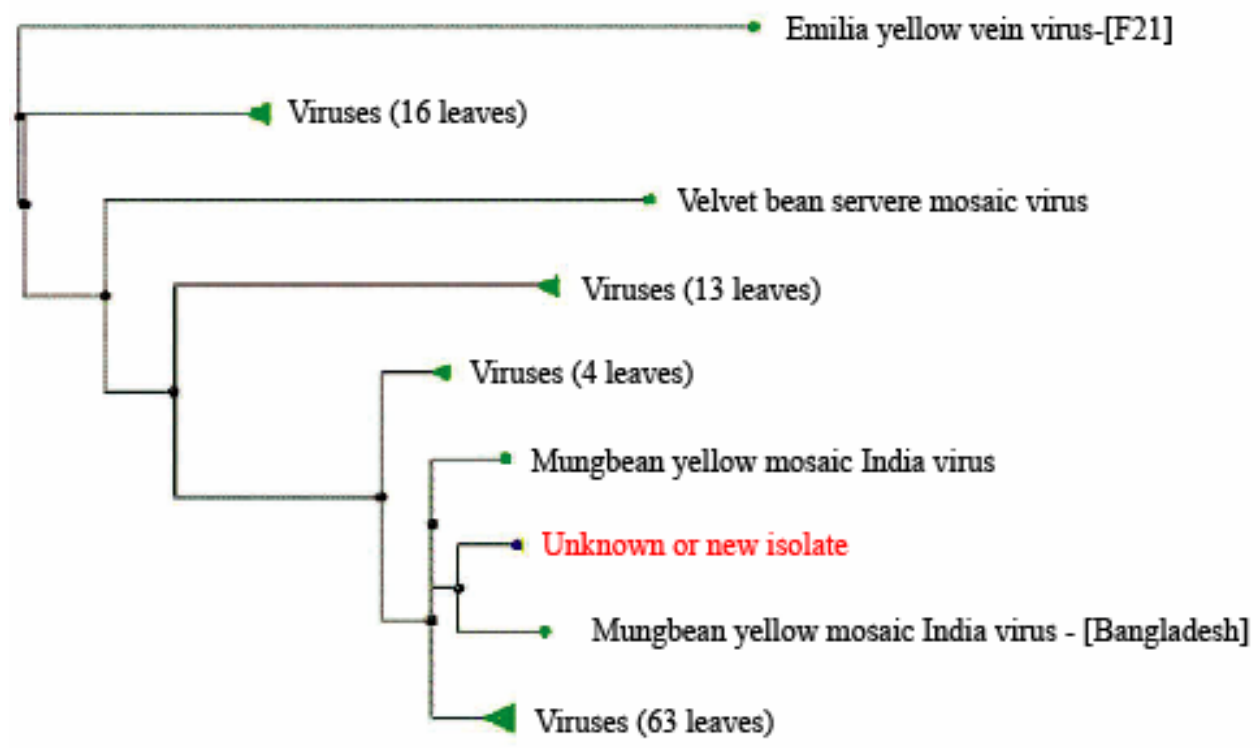

Fig. 3. Phylogenetic relationship of new MYMV isolate on the basis of $\mathrm{CP}$ gene sequence with geminiviruses reported world-wide.

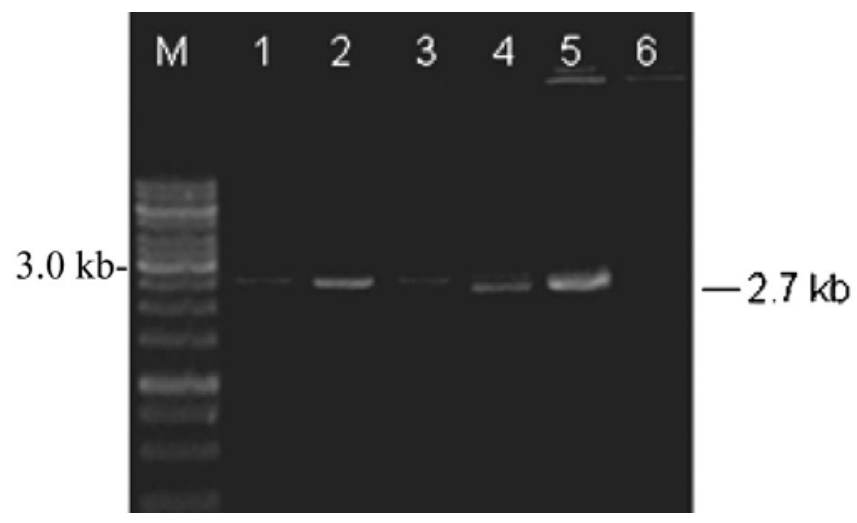

Fig. 4. Rolling circle amplification of viral geneome was performed using $\phi 29$ polymerase following manufacturer's guideline. Rolling circle amplified DNA samples were digested with BamHI enzyme was resolved into $0.8 \%$ agarose gel. Lane M $1.0 \mathrm{~Kb}$ ladder, lanes 1 and 2 SAU sample and lanes 3 and 4 Gazipur sample, lane 5 RCA positive control of pUC 19 DNA and lane 6 RCA negative control using non-infected sample.

The molecular characterization of viruses with circular genome has become very convenient with the use of the Rolling Circle Amplification (RCA) technique (Fire and $\mathrm{Xu}$ 1995). Since MYMIV-BD is circular DNA virus, digestion with BamHI restriction enzyme of the RCA product showed the presence of a $\sim 2.7 \mathrm{~kb}$ product, characteristic of its size, in case of samples collected from both SAU 
campus and Gazipur (Fig. 4). Pandey et al. (2010) has reported similar findings in case of identification of ToLCV, a member of the genus begomovirus causing tomato leaf curl disease.

The result presented here clearly indicated that the primer pair designed in this study can be used for molecular diagnosis of mungbean yellow mosaic virus infection using PCR based technology and part of the CP gene isolated through PCR could also be used for developing antiviral vector by cloning into a suitable plant transformation vector in an antisense orientation.

\section{Acknowledgements}

Authors are thankful to the University Grants Commission, Bangladesh, USDA (Grain Legume Improvement Project) for providing partial financial support and Centre for Advanced Research in Sciences, University of Dhaka for providing sequencing facilities.

\section{References}

Ahmed KP, Bendahmane M, Matzeit V, Accotto GP, Crespi S and Gronenborn B (1991) Tomato yellow leaf curl virus from Sardinia is a whitefly transmitted monopartite geminivirus. Nucleic Acids Res. 19: 6763-6769.

Asurmendi S, Berg RH, Koo JC and Beachy RN (2004) Coat protein regulates formation of replication complexes during tobacco mosaic virus infection. Proc. Natl. Acad. Sci. (USA) 101: 1415-1420.

Islam MN, Islam MN and Mukherjee SK (2011) Construction of MYMIV based gene silencing vector and its use. ISBN: 978-3-8443-8820-6. LAP-LAMBERT Academic Publishing GmbH \& Co. KG. Dudweiler Landstr. 99, 66123 Saarbrücken, Germany.

Fire A and Xu SQ (1995) Rolling replication of short DNA circles. Proc. Natl. Acad. Sci. USA 92: 4641-4645.

Morinaga T, Ikegami M and Miura K (1993) The nucleotide sequence and genome structure of Mungbean yellow mosaic geminivirus. Microbiol. immunol. 37(6): 471-6.

Navot N, Pichersky E, Zeidan M, Zamir D and Czosnek H (1991) Tomato yellow leaf curlvirus: A whitefly-transmitted geminivirus with a single genomic component. Virology 185: 151-161.

Nene YL (1972) A survey of viral diseases of pulse crops in Uttar Pradesh. Uttar Pradesh Agricultural University, Pantnagar, Research Bulletin No. 4, p.191.

Nariani TK (1960) Yellow mosaic of mung (Phaseolus aureus L.). Indian Phytopathol. 13: 24-29.

Prins M, Laimer M, Noris E, Schubert J, Wassenegger $\mathbf{M}$ and Tepfer M (2009) Strategies for antiviral resistance in transgenic plants. Mol. Plant Pathol. 9: 73-83.

Pandey P, Mukhopadhya S, Naqvi AR, Mukherjee SK, Shekhawat GS and Choudhury NR (2010) Molecular characterization of two distinct monopartite begomoviruses infecting tomato in India. Virol. J. 7: 337-347. 
Powell-Abel PA, Nelson RS, De B, Hoffman N, Rogers SG, Fraley RT and Beachy RN (1986) Delay of disease development in trangenic plants that express tobacco mosaic virus coat protein gene. Science 232: 738-743.

Qu F, Ren T and Morris TJ (2003) The coat protein of turnip crinkle virus suppresses post transcriptional gene silencing at an early initiation step. J. Virol. 77: 511-522.

Reichert VL, Choi M, Petrillo JE and Gehrke L (2007) Alfalfa mosaic virus coat protein bridges RNA and RNA-dependent RNA polymerase in vitro. Virology 364: 214-226.

Register JC and Beachy RN (1988) Resistance to TMV in transgenic plants results from interference with an early event in infection. Virology 166: 524-532.

Rybicki EP (1998) A proposal for naming geminiviruses: A reply by the Geminiviridae study Group Chair. Archive of Virology 143: 421-424.

Stanley J (1983) Infectivity of the cloned geminivirus genome requires sequences from both DNAs.

Thomas JE, Massalski PR and Harisson BD (1986) Production of monoclonal antibodies to African cassava mosaic virus and differences in their reactivities with other whitefly transmitted Geminiviruses. J. Gen. Virol. 67: 2739-2748. 